Jurnal Psikologi, Volume 1 nomor 1, November 2020

\title{
PENGARUH PERKULIAHAN DAN TUGAS SECARA DARING TERHADAP MAHASISWA
}

\author{
THE EFFECT OF ONLINE COLLEGE AND TASK FOR COLLEGE STUDENT
}

Reza Agusta Wirakesuma

Program Studi Psikologi, Fakultas Kedokteran, Universitas Lambung Mangkurat

Jl.A. Yani Km 36 Banjarbaru Kalimantan Selatan Kode Pos 70714, Indonesia

E-mail :2010914310024@mhs.ulm.ac.id No. Handphone :082397045030

\begin{abstract}
ABSTRAK
Saat ini seluruh dunia sedang berada di masa pandemi. Pandemi yang menyebabkan ini semua yaitu covid-19. Selama masa pandemi orang-orang dilarang untuk bertemu langsung dan harus menjaga jarak. Hal tersebut dilakukan guna menghentikan virus covid-19. Karena tidak bisa bertemu langsung maka semua dilakukan secara daring. Kegiatan secara daring ini sangat berdampak terhadap kegiatan-kegiatan manusia. Tidak terkecuali sebagai seorang mahasiswa. Kegiatan mahasiswa yang sebelumnya konvensional menjadi kini semua dilakukan secara online. Tugas secara daring memberi dampak tersendiri terhadap mahasiswa. Karena itulah dilakukan penelitian ini.Metode penelitian yang digunakan adalah kajian studi literatur dari berbagai jurnal, buku, observasi \& wawancara. Subjek penelitian berjumlah 5 orang. Tujuan dari penelitian ini adalah untuk mengetahui dampak dari perkuliahan dan pemberian tugas secara daring terhadap mahasiswa.
\end{abstract}

Kata kunci : covid-19,tugas secara daring, mahasiswa

\begin{abstract}
The whole world is currently in a pandemic. The pandemic that caused this is all covid-19. During the pandemic people are forbidden to meet in person and must keep their distance. This is done to stop the covid-19 virus. Because you can't meet in person, it's all done online. This online activity has a huge impact on human activities. No exception as a student. Student activities that were previously conventional are now all done online. Online assignments have an impact on students. That's why this research was done. The research method used is the study of literature studies from various journals, books, observations \& interviews. The study subjects numbered 5 people The purpose of this research is to find out the impact of online assignments on students.
\end{abstract}

Keywords : covid-19, online tasks, students 


\section{PENDAHULUAN}

Covid-19 mengharuskan menjadi daring. Tidak terkecuali sebagai seorang mahasiswa yang dimana sebelum masa covid-19, hari-hari kuliah dijalani secara konvensional. Secara konvensional perkuliahan menjadi lebih mudah dan lebih efektif jika dibandingkan secara daring. Secara daring, sering kali terjadi banyak kendala. Namun mau tidak mau seorang mahasiswa harus bisa melaluinya. Seorang mahasiswa setidaknya pasti mempunyai sebuah alat yaitu laptop. Laptop sangatlah penting dalam menjalani perkuliahan. Kendala dalam daring bukanlah laptop. Kendala mahasiswa berada pada kekuatan sebuah jaringan dan banyaknya kuota yang habis dipakai untuk kuliah. Semua hal ini membutuhkan uang. Perekonomian tiap orang berbeda-beda. Beruntung jika mahasiswa berada dalam keluarga yang mampu. Bayangkan jika termasuk kategori kurang mampu. Betapa susahnya kehidupan perkuliahan. Hal inilah yang menyebabkan konvensional lebih mudah daripada daring. Keefektifan perkuliahan konvensional lebih tinggi dibandingkan secara daring. Sedangkan kebutuhan kuliah daring lebih tinggi dari kuliah konvensional. Selain faktor ekonomi dan faktor keefektifan perkuliahan, masih banyak faktor lainnya. Tapi pendidikan harus tetap ditempuh. Menurut Amini, Mayangsari, \& Zwagery (2020) pendidikan merupakan hal penting dalam kehidupan seseorang dan tahapan tertinggi dalam pendidikan yaitu menjadi seorang mahasiswa. Mahasiswa dituntut untuk dapat belajar dan mengerjakan tugas dengan mandiri. Namun pada kenyataannya tidak semua mahasiswa mampu belajar dan mengerjakan tugas dengan mandiri menurut Amini, Mayangsari, \& Zwagery (2020). Pemberian tugas secara daring dan konvensional tidaklah berbeda. Respon mahasiswa yang beragam. Tetapi kebanyakan mahasiswa jenuh dengan kuliah daring. Karena tidak bisa bertemu dengan teman-teman satu angkatan dan orang-orang.

Tugas secara daring tidak hanya menambah beban mahasiwa tetapi juga beban dosen. Kuliah konvensional membuat tugas-tugas kuliah secara konvensional. Kuliah daring membuat tugas-tugas secara daring. Komitmen terhadap tugas yang diberikan berbeda. Kuliah daring membuat mahasiswa cenderung menjadi lebih mudah jenuh dan menambah tingkat stress mahasiswa. Ditambah dengan tugas kuliah yang sulitsulit. Tetapi Individu dituntut untuk mandiri agar dapat melakukan tugas dan tanggung jawab yang diharapkan (Amini, Mayangsari, \& Zwagery (2020).

Seorang mahasiswa membutuhkan sesuatu yaitu motivasi. Motivasi merupakan sesuatu yang dapat meningkatkan semangat mahasiswa. Mayoritas mahasiswa mengerjakan sesuatu secara prokastinasi atau yang biasa disebut dengan SKS (Sistem Kebut Semalam). Kualitas mahasiswa yang baik dapat dilihat melalui sikap positif antara lain memiliki kecerdasan adversitas yang tinggi, motivasi belajar yang baik dan tidak melakukan penundaan atau prokrastinasi akademik menurut Rachmah, Mayangsari, \& Akbar (2015). Prokrastinasi merupakan sebuah budaya dari mahasiswa. 


\section{METODE PENELITIAN}

Metode penelitian yang digunakan adalah kajian studi literatur dari berbagai jurnal dan buku yang dicari secara daring, observasi dan wawancara dengan mahasiswa yang berada di lingkungan sekitar. Dalam metode wawancara, diajukan berbagai pertanyaan-pertanyaan. Pertanyaan pertama yaitu tentang kuliah secara daring. Pertanyaan kedua yaitu pendapat tentang pandemi covid-19. Pertanyaan ketiga yaitu pendapat tentang pemberian tugas secara daring. Pertanyaan keempat yaitu pendapat tentang prokrastinasi. Pertanyaan kelima yaitu pengaruh prokrastinasi terhadap nilai suatu tugas. Pertanyaan keenam yaitu pendapat tentang nilai apakah penting atau tidak penting. Tujuan dari penulisan ini adalah untuk mengetahui pengaruh dari kuliah dan pemberian tugas secara daring terhadap mahasiswa.

\section{HASIL DAN PEMBAHASAN}

Subjek terdiri 5 orang. Pertama,pertanyaan tentang kuliah secara daring. Berdasarkan hasil observasi dan wawancara, 4 subjek tidak setuju dengan kuliah secara daring. 1 subjek tidak peduli dengan kuliah secara daring. Mayoritas subjek mengatakan kuliah daring tidak efektif dan tidak menyenangkan. Sulit untuk memahami materi karena kuliah secara daring. Dibutuhkan fokus dan komitmen dalam mengerjakan sesuatu (Hidayatullah \& Zwagery (2018)). Menurut subjek kuliah daring memiliki banyak celah dan sangat tidak efisien. Tetapi hal ini satu-satunya cara agar perkuliahan tetap berlanjut. Manfaatkan kesempatan sebaik mungkin. Jangan mencari kesempatan dalam kesempitan.Kedua, pertanyaan tentang pandemic covid-19. Semua subjek setuju covid-19 penyebab dari kuliah daring dan akar dari semua permasalahan di dunia saat ini. Mahasiswa tidak bisa berinteraksi dengan mahasiswa lain secara langsung dalam waktu yang lama membuat tingkat stress meningkat. Perlu motivasi yang kuat agar bisa melalui hal ini. Motivasi belajar telah lama menjadi faktor penentu dalam prestasi belajar seseorang menurut Rachmah, Mayangsari, \& Akbar (2015). Ketiga, pertanyaan tentang tugas secara daring. Mayoritas subjek menggunakan prokrastinasi atau SKS dalam pengerjaan tugas. 1 Subjek lebih memilih mengerjakan tugas dengan cara menyicil, dengan alasan agar tidak menambah beban. Dilanjutkan dengan pertanyaan keempat. Semua subjek tidak mengetahui dengan prokrastinasi, hanya tahu dengan istilah SKS. Menurut semua subjek prokrastinasi merupakan hal yang wajar dan sudah ada dan sudah pernah dilakukan sebelum menjadi mahasiswa. . Individu yang memiliki motivasi yang rendah dalam mengerjakan tugas cenderung dapat memunculkan prokrastinasi akademik tinggi dan sebaliknya individu yang memiliki motivasi yang tinggi tidak akan mengalami prokrastinasi akademik yang berlebihan sehingga mengganggu aktivitas mereka (Rachmah, Mayangsari, \& Akbar (2015). Kelima, pertanyaan tentang pengaruh prokrastinasi terhadap nilai. Semua subjek setuju prokrastinasi sangat berpengaruh terhadap nilai. Tugas yang dikerjakan mencapai hasil yang kurang memuaskan dan kurang maksimal, namun itu merupakan resiko dari prokrastinasi yang harus ditanggung. (Rachmah, Mayangsari, \& Akbar (2015)( Rumiani (2006:44) juga menyebutkan bahwa mahasiswa yang memiliki kegigihan yang tinggi, dan pantang menyerah terhadap permasalahan, selalu berorientasi pada tujuan, tidak akan 
membiarkan dirinya melakukan prokrastinasi akademik. Pertanyaan terakhir yaitu pentingnya nilai. Semua memiliki pendapat yang berbeda. Ada yang menganggap penting, ada yang menganggap tidak penting, ada yang tidak peduli sama sekali. Penting adanya komitmen terhadap tugas pada mahasiswa agar dapat menghindari terlambatnya mahasiswa dalam mengumpul tugas dan menghindari mahasiswa mendapat nilai pas-pasan (Amini, Mayangsari, \& Zwagery (2020).

\section{KESIMPULAN}

Kuliah daring tidak efektif, kurang efisien, dan tidak menyenangkan. Membuat mahasiwa menjadi lebih stress dari yang sebelumnya. Terdapat banyak celah dalam kuliah daring. Tugas secara daring tidak berbeda dengan tugas konvensional. Prokrastinasi merupakan budaya mahasiswa. Memerlukan motivasi dan kesabaran dalam menjalani perkuliahan secara daring.

\section{DAFTAR PUSTAKA}

Abbas, E. W. (2014). Pendidikan Karakter.

Abbas, E. W., \& Erlyani, N. (2020). Menulis di Kala Badai Covid-19.

Amini, M., Mayangsari, M. D., \& Zwagery, R. V. (2020). Hubungan antara Kemandirian Belajar dengan Komitmen Tugas pada Mahasiswa Program Studi Psikologi. Jurnal Kognisia: Jurnal Mahasiswa Psikologi Online, 2(2), 149152.

Hidayatullah, M. S., \& Zwagery, R. V. (2018). EFEKTIVITAS PELATIHAN GOAL SETTING UNTUK MENINGKATKAN KOMITMEN TUGAS PADA SISWA SMPN 1
MARTAPURA

TIMUR. Jurnal

Ecopsy, 5(1), 16-21.

Rachmah, D. N., Mayangsari, M. D., \& Akbar, S. N. (2015). Motivasi belajar sebagai mediator hubungan kecerdasan adversitas dan prokrastinasi akademik pada mahasiswa yang aktif berorganisasi. Jurnal Cakrawala Pendidikan, 34(2).

Shadiqi, M. A. Memahami dan Mencegah Perilaku Plagiarisme dalam Menulis Karya Ilmiah. Buletin Psikologi, 27(1), 30-42. 